\title{
De Viajeros y dibujantes: el Monasterio de San Lorenzo de El Escorial, entre el mito y la leyenda
}

\author{
Pilar Chías \\ Tomás Abad
}

Abstract

El conjunto del Monasterio de El Escorial nunca ha dejado a nadie indiferente, suscitando en cinco siglos una gran cantidad de mitos y de leyendas. Mitos que en los siglos XVI y XVII se asociaron directamente a la imagen de su fundador, el rey Felipe II, y al papel de la Corona de España como salvaguarda del Catolicismo, y que mostraron el edificio como un nuevo Templo de Salomón, como la Ciudad de Dios de San Agustín y como el compendio de las pautas arquitectónicas e iconográficas de la Contrarreforma. Tras los excesos del Barroco, las pugnas estilísticas en favor del Neoclasicismo quisieron convertirlo, en manos de las Academias y debido a su sobriedad formal, en el modelo a imitar. Medio siglo después, los viajeros e ilustradores del Romanticismo asociaron el conjunto a la imagen de un rey fundador tirano y solitario y a un país oscurantista, tan alejada de la realidad como rentable. Finalmente, en la Posguerra de mediados del siglo $X X$, el conjunto se vinculó a la representación en piedra del Imperio Español perdido. Por otra parte, la escala monumental del edificio, los numerosos sucesos históricos que en él han tenido lugary su carácter de panteón real, ha propiciado la aparición de un gran número de leyendas que lo asocian a prácticas mágicas, en las que aúllan perros negros y existen tesoros escondidos. Imágenes que constituyen un testimonio visual de la historia de un patrimonio extraordinario.

Palabras clave

arquitectura, España, siglos XVI-XX, dibujos de arquitectura, apuntes de viaje.

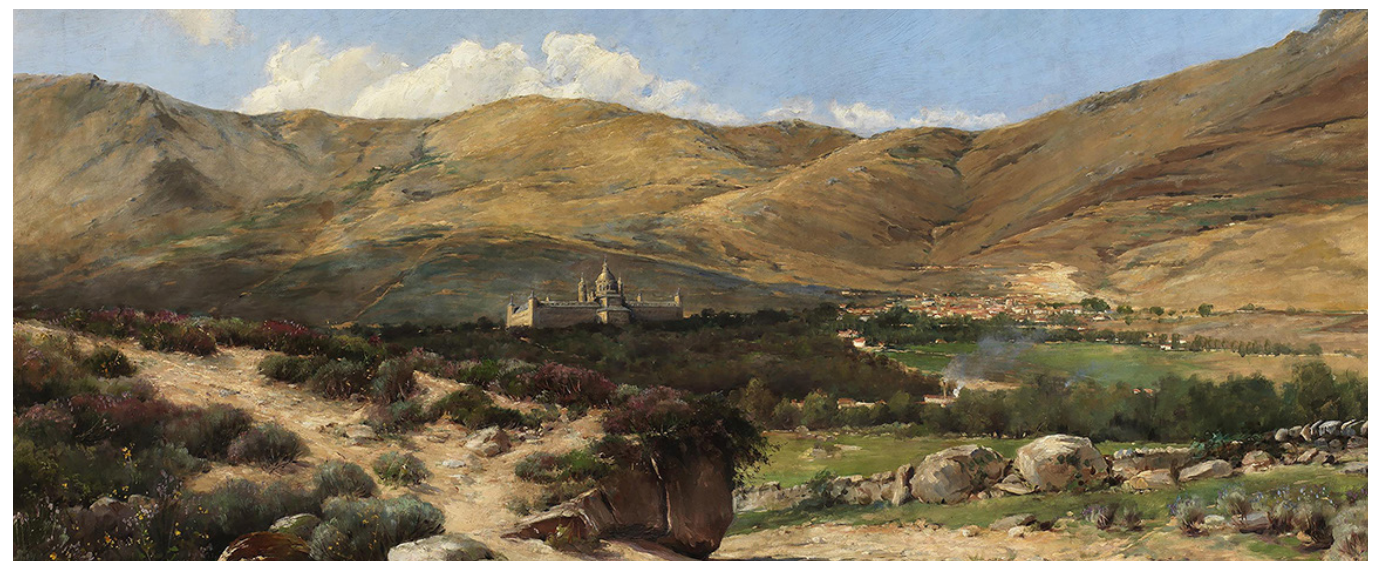




\section{Introducción. Objetivos y metodología}

Desde su fundación en 1563 y debido a su excepcional valor patrimonial e histórico, el Monasterio de El Escorial ha sido la imagen en piedra -"la piedra lósica" de Ortega y Gasset (1916-1934) [Ortega y Grasset 1966, vol. II, pp. 658-664]- de numerosas ideas e interpretaciones. Su gran fábrica aparecía ante los ojos de los visitantes recortándose frente a la imponente montaña de Abantos suscitando sensaciones diversas y en muchos casos mediatizadas por el gusto estético y los sucesos de la época.

El objetivo es, pues, analizar los mitos que a través de los escritos y de los dibujos se han ido forjando en paralelo durante siglos en torno al Monasterio, y cómo aquéllos han afectado a su imagen y a sus valores objetivos. La metodología que hemos utilizado ha consistido en una primera fase dedicada a realizar una exhaustiva búsqueda documental en bibliotecas, archivos y museos, que nos ha proporcionado una visión amplia de los textos y las imágenes que se realizaron en cada época histórica. A continuación, realizamos una categorización de los distintos documentos atendiendo a los periodos más característicos, que hemos resumido en: I) los panegiristas del rey fundador y de su obra; 2) la recuperación del Escorial como modelo por las Academias; 3 ) los viajeros románticos; 4) los excursionistas y las guías para viajeros; 5) el Monasterio y la imagen del Imperio perdido. A partir de esta clasificación hemos realizado una selección de los ejemplos gráficos y escritos más significativos, y hemos comparado los textos y los dibujos para comprobar su nivel de coincidencia y complementariedad, y plantear la oportuna discusión sobre los distintos enfoques.

En paralelo hemos realizado un breve recorrido por las principales leyendas que aún se ciernen sobre el conjunto, cuyo principal interés radica en que son el reflejo del momento histórico en el que surgieron.

Las conclusiones recogen las principales reflexiones en torno al paralelismo de ambos tipos de documentación y su vinculación a las modas y los hechos históricos.

Aparte de otros trabajos de los autores [Chías 2013; Chías 20 I6; Chías, Abad 20 I5; Chías, Abad 2018] no existen muchos precedentes con este enfoque, pero merecen citarse los capítulos de López Torrijos [López Torrijos 1985] y de Santiago Páez y Magariños [Santiago Páez y Magariños 1985] en el catálogo de la exposición celebrada en la Biblioteca Nacional, así como varias contribuciones al interesante simposio sobre Literatura e Imagen en El Escorial dirigido por Campos y Fernández de Sevilla [Campos y Fernández de Sevilla 1996].

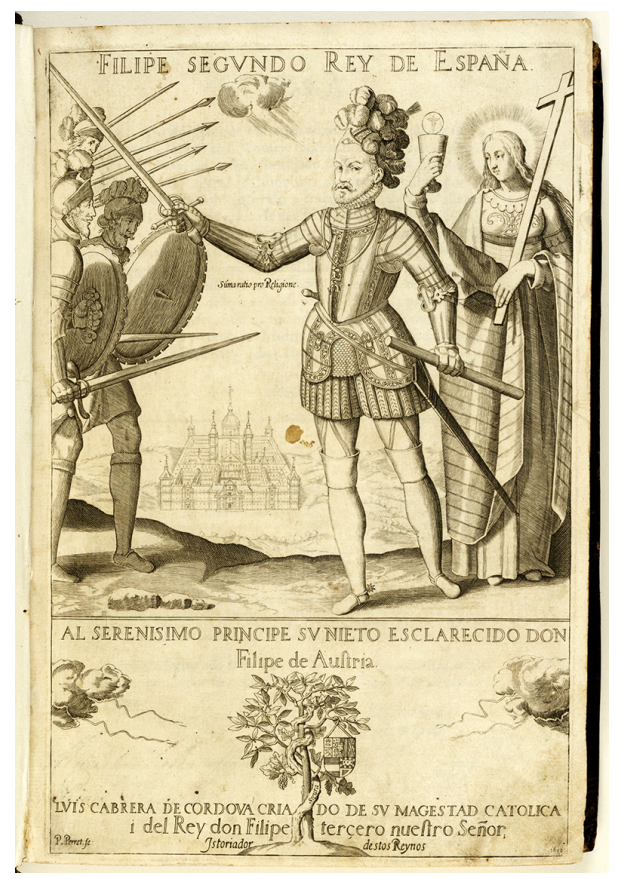




\section{La imagen de los panegiristas del siglo XVI: el Templo de Salomón, la Ciudad de Dios y la materialización de la Contrarreforma}

Durante los siglos XVI y XVII predominó la imagen oficial de los panegiristas de Felipe II, incluso cuando se fue imponiendo el gusto barroco en clara oposición a la sobriedad ornamental del Monasterio."Fue edificada esta máquina grande, rica, santa, artificiosa, provechosa, la octava maravilla del mundo en orden, i la primera en dignidad, [...] en verguença i confusion de ereges enemigos de la Iglesia catolica, que con inpiedad i tiranía asolaban los Tenplos en tantas provincias, para que viesen que no se cansaba [el rey] de favorecer i anparar la fe Cristiana contra ellos con las armas: pero continuamente la ampliaba i edificaba Tenplo tan grande quanto era su fe, ennobleciendo a España" [Cabrera I619, Libro VI, p. 3I5]. En este periodo las virtudes del rey, considerado un nuevo Salomón sabio y prudente y un defensor a ultranza del catolicismo y de las ideas de la Contrarreforma (fig. I), llevaron a comparar el Monasterio con el Templo de Jerusalén, a la vez que condicionaban de modo esencial la iconografía del conjunto. Las estrictas condiciones impuestas por Trento afectaron de modo esencial a la iconografía en las pinturas y esculturas, tendentes a evitar distracciones del mensaje principal.

Por otra parte, la Orden Jerónima seguía la regla de san Agustín, por lo que la asimilación del Monasterio a la Ciudad de Dios fue también una imagen recurrente, como se puede apreciar en el modelo simplificado del edificio que aparece representado sobre el libro de san Agustín [Estal 1964, p. 578], (fig. 2).

Fig. 2. Alonso Sánchez Coello, 1580: San Jerónimo y san Agustín. Monasterio de El Escorial.

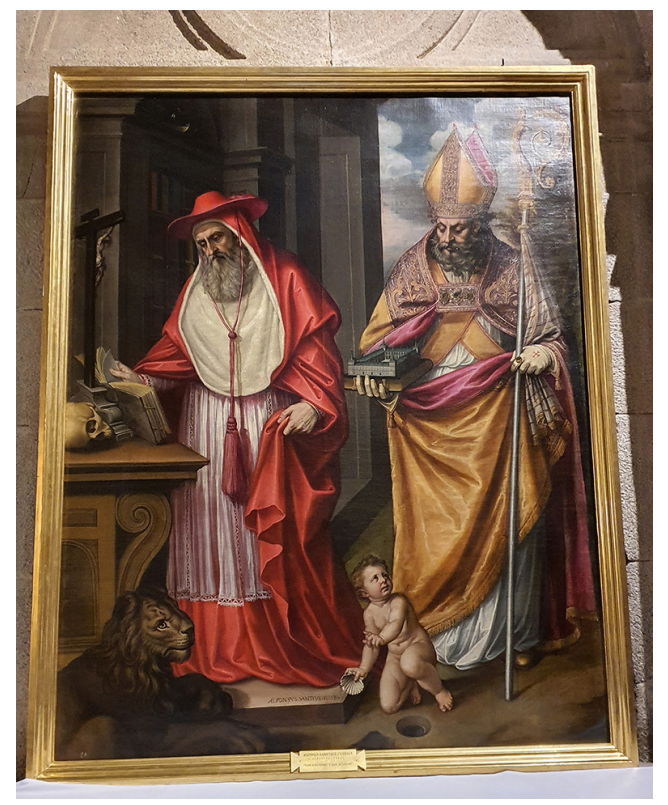

\section{El Escorial y la Academia}

Con el cambio de gusto liderado por las Academias de Bellas Artes, El Escorial volvió a ser objeto de interés y de estudio para servir de referente a la nueva arquitectura clásica, retomando la tradición de autores como Juan de Arfe y Diego de Siloé para quienes el Monasterio era la plena asimilación en España de la llamada "arquitectura restaurada, la antigua de los Griegos y Romanos" [Arfe y Villafañe I585- I587, Título I, Libro IV].

Con tal fin y por iniciativa del Conde de Aranda, José de Hermosilla auxiliado por los ingenieros militares Fillera y Bécaud, realizó entre 1757 y 1759 un levantamiento preciso del Monasterio que debía haber servido de base para realizar una serie de grabados, con los que se pretendía asegurar la difusión de su imagen; éstos debían correr a cargo de la Real Academia de San Fernando. 
Estos magníficos planos manuscritos dibujados a gran escala fueron publicados recientemente por Chías [Chías 2017] y se integran en esta corriente estilística que pretendía revitalizar la imagen del Monasterio a causa de su austeridad ornamental, que se ha visto también recogida en otros dibujos contemporáneos (fig. 3).

Continuando con esta tendencia, el rey Carlos III enviaría a la Academia en 1765 una colección de diez Estampas de Herrera y Perret "a fin de que sirvan en ella de estudio a los discípulos de Arquitectura" [López Serrano 1944, p. 5].

A la muerte del rey, sería Campomanes quien mejor resumiría el espíritu de la época: "¡Qué sublimidad, qué belleza inexplicable tiene una sencillez majestuosa, en que se admira el arte y no se conoce el artificio!" [Descripción 1789].

Fig. 3. Torcuato José Benjumeda, 1793: Trampantojo arquitectónico. Biblioteca

Nacional de España,

Madrid.

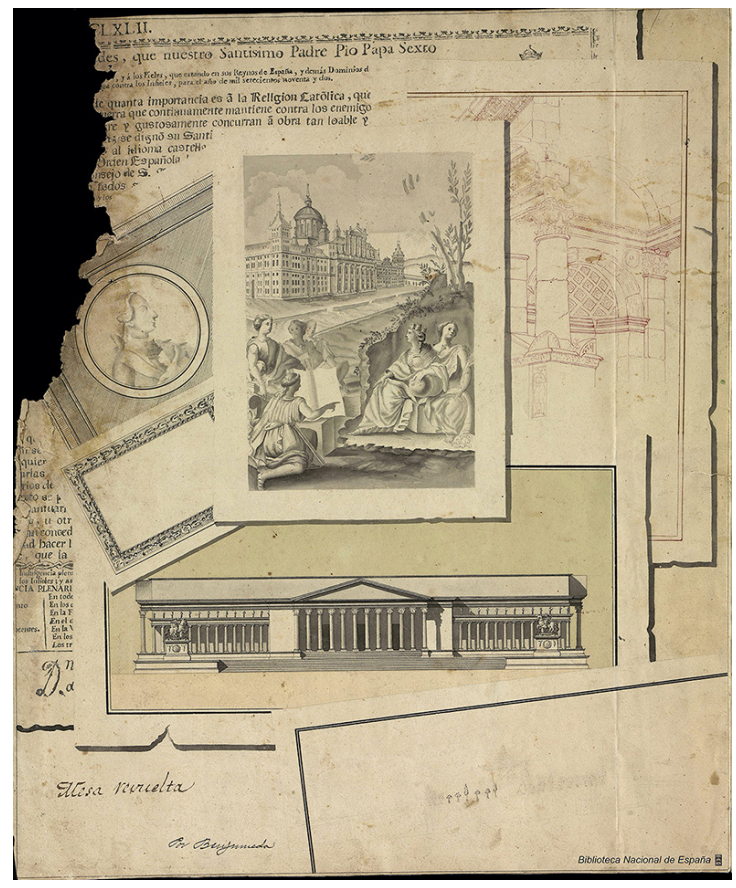

\section{Los viajeros románticos}

Después de este breve periodo Neoclásico, la nueva estética del Romanticismo difundió de la mano de escritores y viajeros la imagen de una España pintoresca y atrasada, habitualmente exagerada y basada en leyendas de moros, de bandidos y de toreros, que se vio apoyada desde otros ámbitos artísticos como la música -recuérdese la ópera Carmen de Bizet. Así lo resumió Thèophile Gautier: "Une constitution sur l'Espagne, c'est une poignée de plâtre sur du granit" [Gautier 1859, p. 20].

Durante los viajes muchos autores realizaron excepcionales dibujos que aportaron vistas inéditas del Monasterio y de su entorno. En muchos casos los apuntes de viaje fueron reelaborados posteriormente para su difusión, por medio de grabadores de primera fila. Entre los principales dibujantes destacan Chapuy [Chapuy 1842] (fig. 4), Ford [Ford I845], Guesdon [Guesdon I855] y Doré [Davillier, Doré I 874] (fig. 5), por citar algunos destacados ejemplos.

Otros autores optaron por contratar a excelentes dibujantes, como fue el caso de Manuel Cuendias [Cuendias I848] con dibujos de Pannemaker, y de Émile Begin [Begin I852] con dibujos de los hermanos Rouargue.

Estas perspectivas del conjunto escurialense, dibujadas tras los desmanes de la invasión de las tropas de Napoleón y durante la exclaustración de la comunidad jerónima, a pesar de 
la subjetividad que transmite el uso del claroscuro -rozando el tenebrismo- y del pintoresquismo, constituyen una documentación esencial para el estudio del Monasterio y de su entorno durante el siglo XIX, pues muestran detalles como los toldos en la fachada de poniente, el cambio de color de las carpinterías, la aparición de diversos cerramientos en el Muro de los Nichos, y las actividades de los vecinos.

Fig. 4. Nicolas-MarieJoseph Chapuy, 1842: de l'Escurial. En L'Espagne, vues des principales villes de ce royaume dessinées. Lam. 38I.

Fig. 5. Gustave Doré, 1860: L'Escurial: vue générale. En Davillier, Doré 1874, L'Espagne, Dore
p. 617.
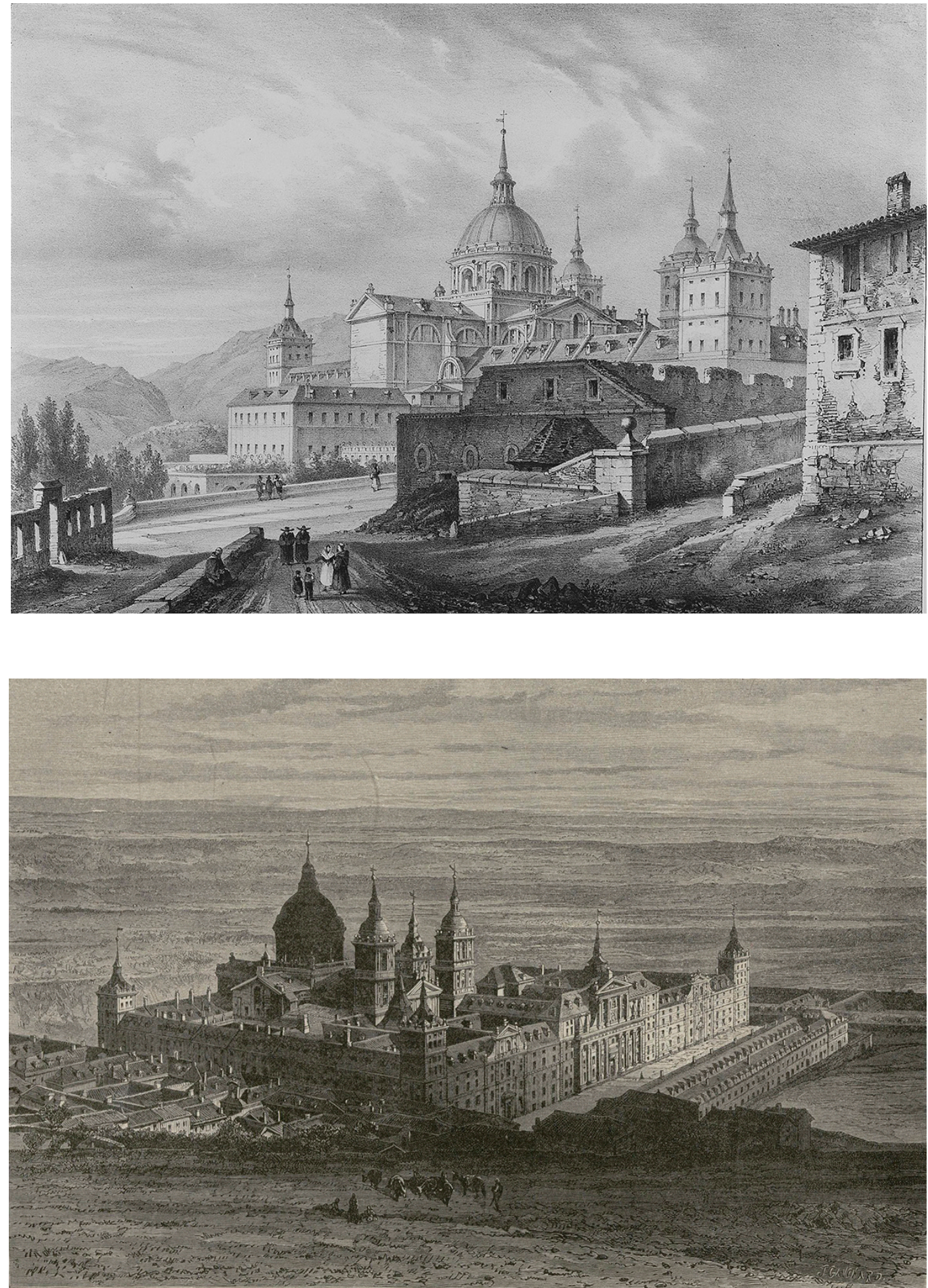


\section{Los excursionistas y las Guías para viajeros}

Entre la segunda mitad del siglo XIX y la Guerra Civil, la imagen del Monasterio fue asociándose progresivamente a un lugar de vacaciones próximo a Madrid, que se vio reforzado a raíz de la accesibilidad por tren al Real Sitio.

En este periodo abundaron las guías, los relatos de los veranos pasados en San Lorenzo, las noticias en revistas ilustradas (fig. 6) y las novelas ambientadas en la sierra. En muchos de ellos aparecen ilustraciones que proporcionan una imagen muy alejada de las anteriores, ahora vinculada a las excursiones (fig. 7) y a una nueva visión de la montaña como fuente de salud y de conocimiento que fomentaba la Institución Libre de Enseñanza.

Y es a Giner de los Ríos a quien se debe un concepto mucho más amplio del paisaje y una mirada comprensiva de aspectos que hasta entonces no se habían tenido en cuenta, como la naturaleza deshabitada y los páramos yermos y desolados. "En su más vigorosa acepción, el paisaje es la perspectiva de una comarca natural como la pintura de paisaje es la representación de esa perspectiva" [Giner 19|5], (fig. 8).

Fig. 6. Alcázar, 1885: El Escorial. Llegada de cortejo fúnebre [del rey Alfonso XII] a la Lonja del Real Monasterio de San Lorenzo. La llustración Espoñola y Americana 8 de diciembre de 1885

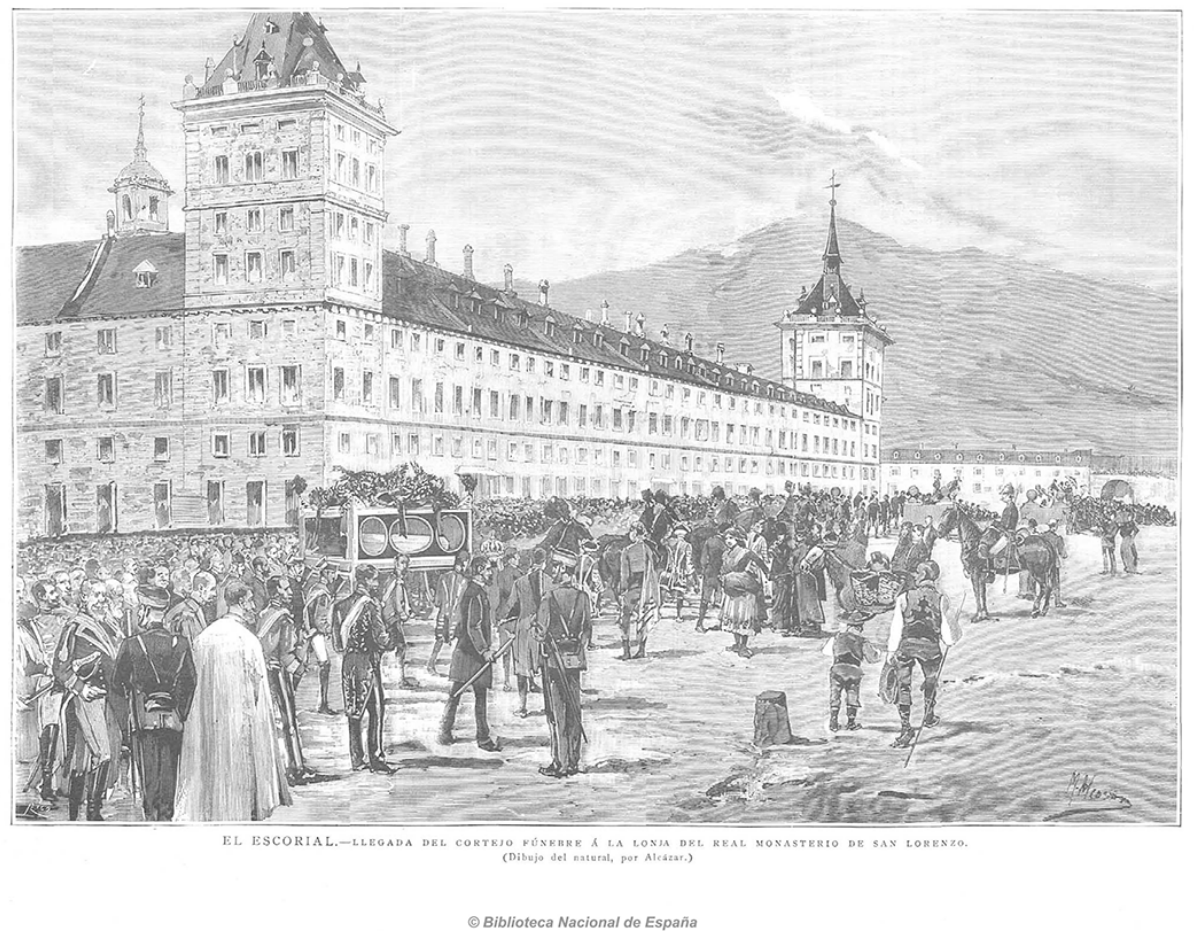

Imagen y nostalgia del Imperio perdido

Desde el advenimiento de la Segunda República en 1931 y durante la dictadura de Franco, el Monasterio pasó a ser un símbolo de la 'Hispanidad'y del gran imperio sobre el que gobernó la Corona Española entre los siglos XVI y XIX, como parte de una estrategia dirigida a recuperar la confianza en el gran potencial del país sobre la base de instrumentalizar el arte y la cultura.

"El primer campo de mitificación nacionalista es siempre la historia", escribió lúcidamente Tomás y Valiente [Tomás y Valiente 1994, p. I 3], y por ello la propaganda buscó asociar el edificio con unas connotaciones que antes no había tenido, y con unos valores presuntamente correspondientes al carácter español.

En parte a causa de la estética empleada en la cartelería (fig. 9), en las portadas (fig. 10), en los sellos postales, en los billetes de curso legal y en otros medios, se suscitaron unos 
Fig. 7. Juan Comba I 882: Viajes de recreo

Escorial. En Sepúlveda y Comba 1883, La vida en Madrid en 1882. Madrid: Librería de Fernando Fe.

Fig. 8. Félix Borrell 1901, Paisaje de El Escorial.

Museo Nacional del

Prado, Madrid.

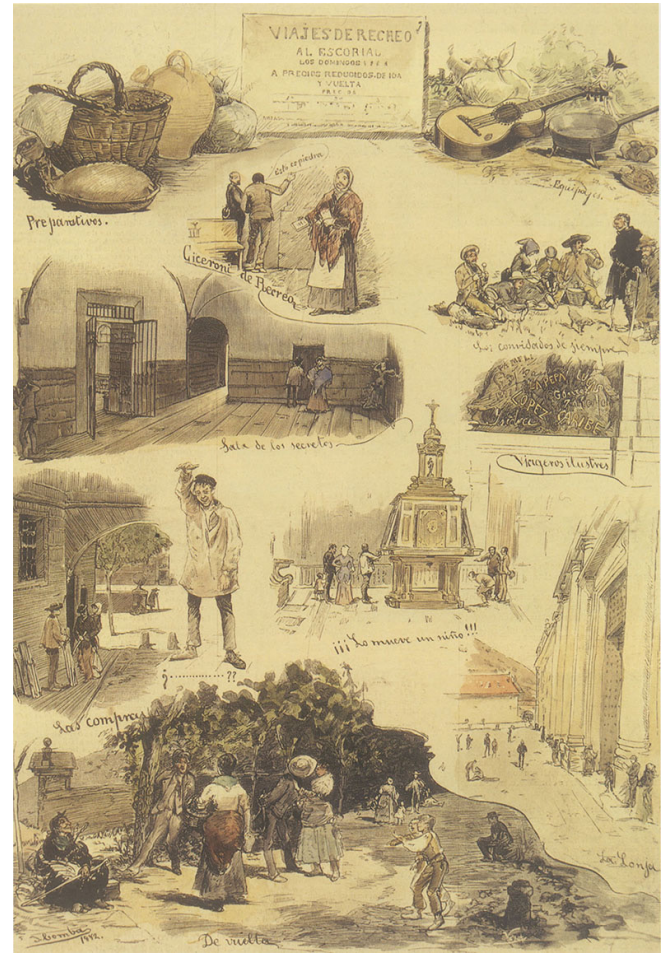

prejuicios completamente ajenos al edificio, que aún subsisten e impiden en muchos casos una aproximación objetiva al mismo.

Particularmente singular es la aparición del Monasterio en dos retratos pintados al óleo por Salvador Dalí -del embajador Juan de Cárdenas de hacia 1943, y otro de la nieta mayor de Franco de 1974-, en los que la potente presencia del edificio constituye un fondo simbólico excepcional.

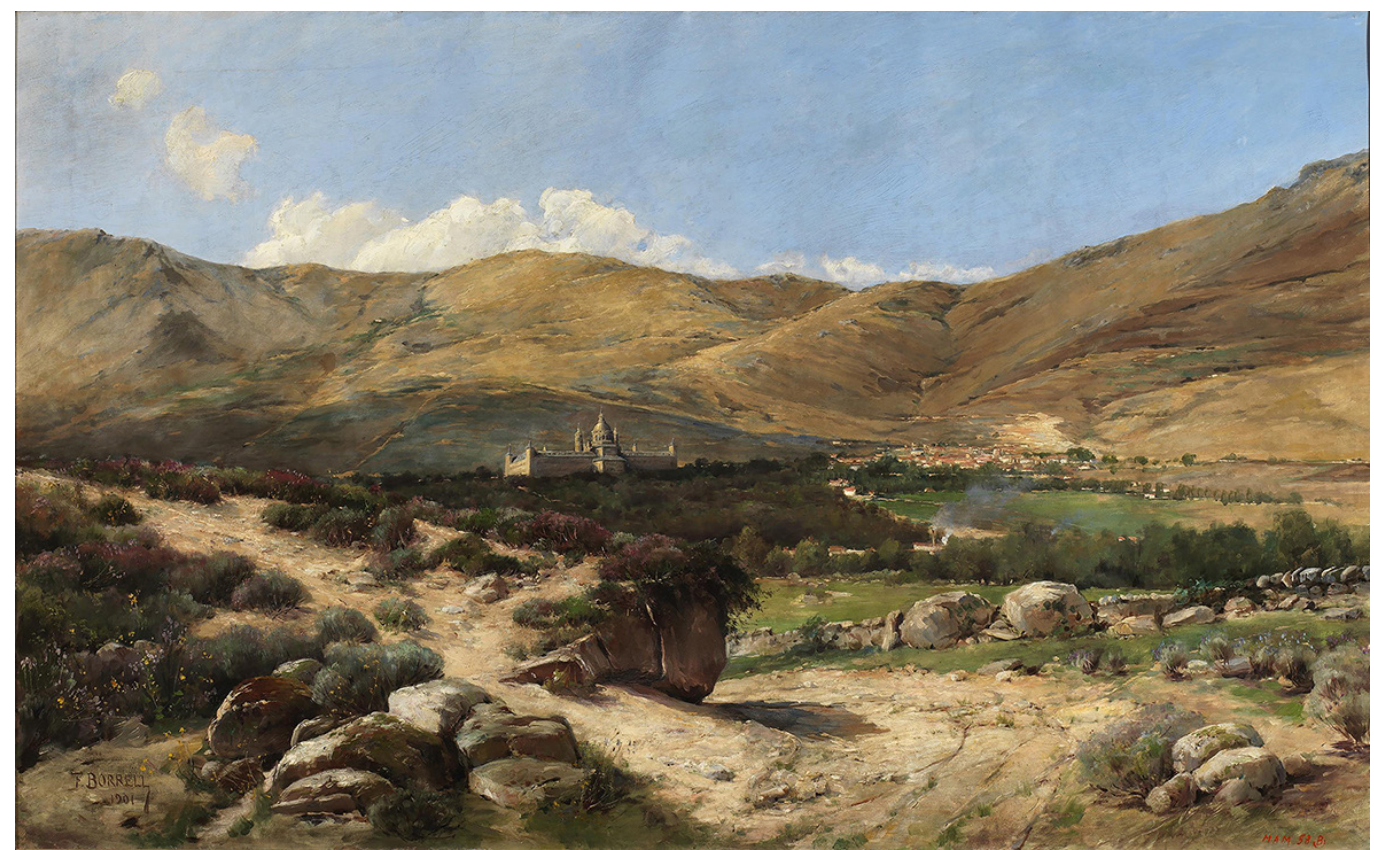


Fig. 9. Cartel de un Congreso de Juventud de Acción Popular, 1934 Biblioteca Nacional de España.

Fig. 10. Carrillo, 1944: Portada del manual escolar España es así. Madrid: Editorial Escuela Española.
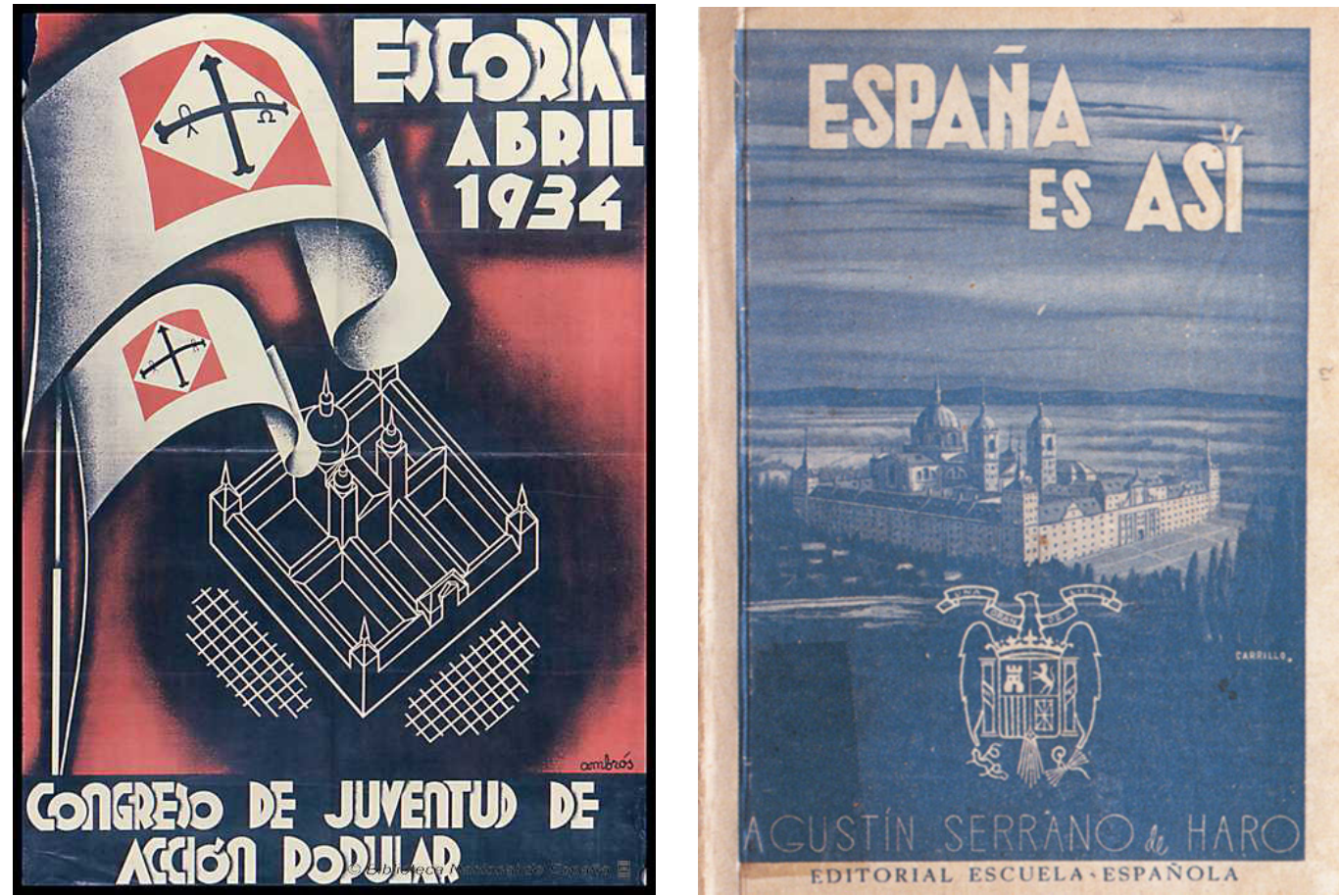

\section{Las leyendas}

Las leyendas que aún están asociadas al Monasterio se forjaron en momentos importantes de su historia como la construcción de la fábrica en el siglo XVI y la invasión de las tropas de Napoleón a principios del XIX.

Entre las intenciones que movieron a Felipe II a construir el edificio se ha creído ver en él el reflejo de un interés heterodoxo del rey -y de Juan de Herrera- por la astrología y los saberes ocultos [Taylor 1967; Kubler 1983, pp. 170- |73]. La biblioteca real (fig. II) y varios frescos reúnen iconografías relacionadas con ellos, pero en realidad son la evidencia de los saberes y la erudición de la época. Sin embargo, la búsqueda posterior de trazados reguladores y de proporciones mágicas en el edificio ha sido incesante y las especulaciones han arrojado tan extraños como forzados resultados.

Otra leyenda, la leyenda del perro negro, tiene su origen en un desafortunado animal que en agosto de 1577 vagaba de noche por las obras aullando por haber perdido a su amo. Refugiado en "la capilla de las escaleras" del jardín, que hacía que sus lamentos resonasen amplificados causando espanto entre los laborantes, que creían que se trataba del demonio, dio "lugar a una mala leyenda contra la casa" [San Jerónimo I59|, ff. 98-98v]. El final no fue feliz, pero algunas noches, confundido con el viento, aún se oye aullar al perro que ronda solitario por el edificio.

Más reciente es la leyenda de la existencia de un tesoro escondido en el interior del Monasterio, que surgió a raíz de la rapiña realizada por las tropas francesas. Cuenta Rotondo [Rotondo 1863, pp. 183, 184, 186] que los frailes acogieron en 1807 a Federico Quillet como a un viajero más cuando en realidad era un enviado de Napoleón para averiguar las alhajas que guardaba el edificio. Advertidos los jerónimos de sus intenciones, cuenta la leyenda que escondieron parte de las riquezas, pero que al fallecer se llevaron el secreto a la tumba y aún permanecen escondidas. 
Fig. I I. Pellegrin Tibaldi, |586-|59|: Dibujo para los frescos de la Biblioteca con anotaciones de Juan de Herrera. British Museum, Londres.

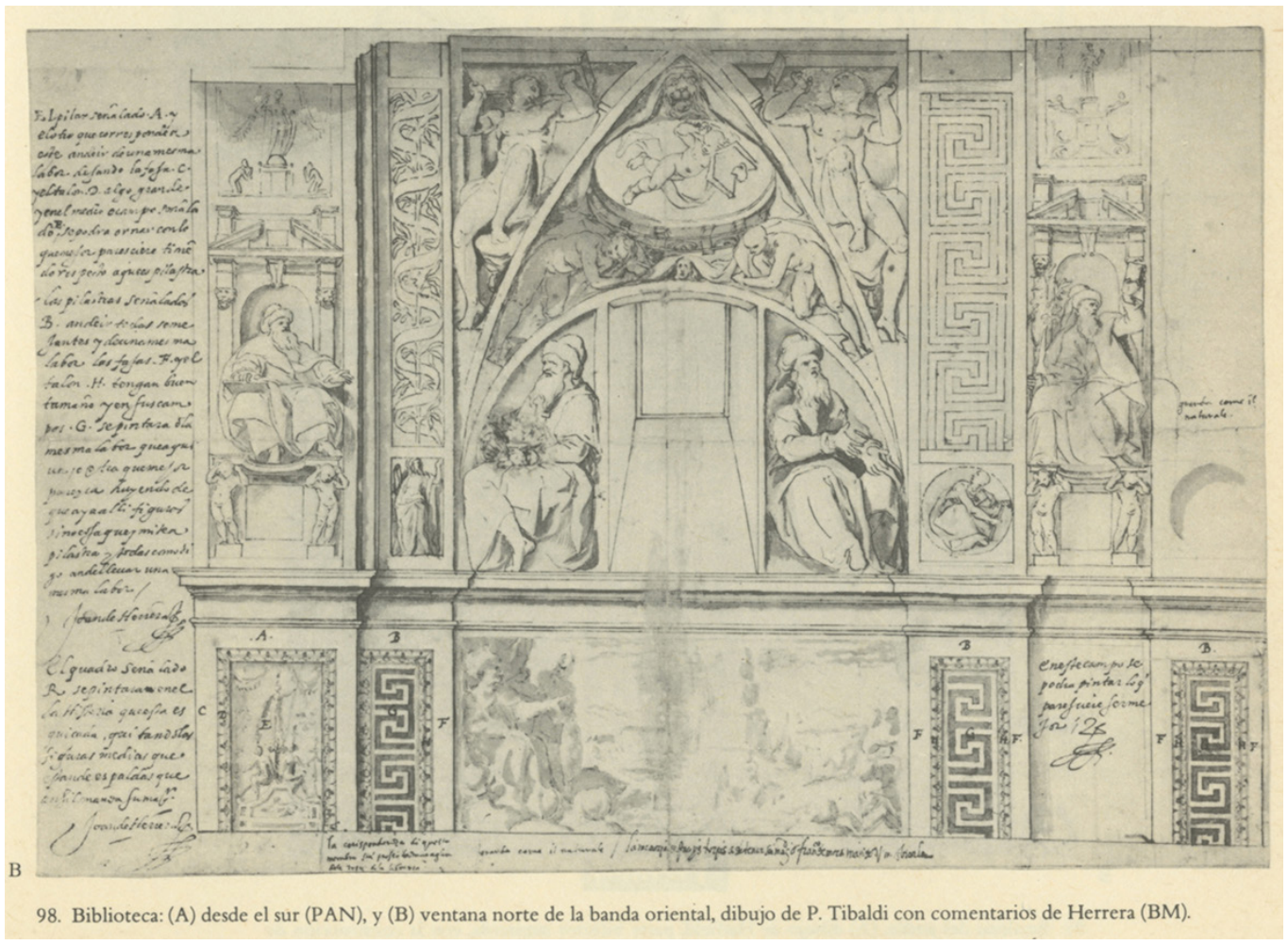

\section{Conclusiones}

El análisis comparativo de los textos y las imágenes pone de manifiesto dos aspectos fundamentales. Por una parte, la complementariedad de ambos discursos, que expresan en paralelo y con medios diferentes una ideología y una estética coincidentes. Y en segundo lugar, que los puntos de inflexión coinciden con los hitos más relevantes en la historia del Monasterio.

De modo análogo, la mayoría de las leyendas han alimentado esta asociación del edificio a fenómenos sobrenaturales o extraños.

Mitos y leyendas evidencian lo que Unamuno resumió certeramente: "Pues lo cierto es que apenas hay quien llegue a visitar El Escorial con ánimo desprevenido y sereno, a recibir la impresión de una obra de arte, a gozar con el goce más refinado y más raro, cual es de la contemplación del desnudo arquitectónico. Casi todos los que a ver El Escorial se llegan, van con anteojeras, con prejuicios políticos y religiosos, ya en un sentido, ya en el contrario; van, más que como peregrinos del arte, como progresistas o como tradicionalistas, como católicos o. como librepensadores. Van a buscar la sombra de Felipe II, mal conocido también y peor comprendido, y si no la encuentran se la fingen" [Unamuno 1922, pp. 48, 49].

\section{Referencias}

Arfe y Villafañe Juan de (I585- 1587). De Varia commensuración para la esculptura y architectura. Sevilla: Andrea Pescioni y Juan de León.

Begin Émile ( 1852$)$. Voyage pittoresque en Espagne et en Portugal. Paris: Belin-Leprieur et Morizot.

Cabrera de Córdoba Luis ( 6 |9). Historia de Felipe Segundo, Rey de España. Madrid: Luis Sánchez, impresor del Rey.

Campos y Fernández de Sevilla Francisco Javier (dir). (1996). Literatura e imagen en El Escorial (Actas del simposium). San Lorenzo de El Escorial: Real Colegio Universitario Ma Cristina.

Chapuy Nicolas-Marie-Joseph ( 1842 ). L'Espagne. Vues des principales villes de ce Royaume dessinées. Paris: Lemercier, Berciard, et Cie. 
Chías Pilar (20।3). Territorio y paisaje en el entorno del Monasterio de San Lorenzo de El Escorial: planos y vistas desde el dibujo de Hatfield House a Guesdon. En Revista EGA n 22, pp. 38-49.

Chías Pilar (20 I 6). La iconografía del Monasterio de El Escorial:Tradición e innovación en cuatro siglos de imágenes impresas. En Revista EGA, 28, 2016, pp. 32-43.

Chías Pilar (2017). Dos siglos de revitalización en la iconografía del Monasterio de el Escorial, I600-I800. En Revista EGA, 29, 22, 2017 , pp. 28-37.

Chías Pilar, Abad Tomás (20I5). La Imagen de San Lorenzo de El Escorial desde las Ordenanzas de Carlos III. En M.A. Chaves (ed.). Arquitectura, Patrimonio y Ciudad. Madrid: Universidad Complutense de Madrid / CSIC, 20 I 5, pp. I05-I I 2.

Chias Pilar, Abad Tomás (2018). From Woodcut engravings to Photography: Printed images of the Monastery of El Escorial in the 19th Century. En Disegnare Idee Immagini, 57, 2018, pp. 36-45.

Cuendias Manuel de, Féréal Victor de (1848). L'Espagne pittoresque, artistique et monumentale: moeurs, usages et costumes. Paris: Librairie Ethnographique.

Davillier Baron Jean Charles, Doré Gustave ( 1874). L'Espagne. Paris: Librairie Hachette et Cie., 79 Boulevard Saint-Germain.

Descripción de los ornatos públicos con que la corte de Madrid ha solemnizado la feliz exaltación al trono de los reyes nuestros señores don Carlos IIII y doña Luisa de Borbón, y la jura del serenísimo señor don Fernando, príncipe de Asturias. En la Imprenta Real de Madrid, 1789.

Estal Gabriel del (1964). El Escorial en la transición de San Jerónimo a San Agustín (Titularidad jurídica y circunstancia histórica). En Monasterio de San Lorenzo el Real, El Escorial, 1964, pp. 578-584.

Ford Richard ( 845$)$. A handbook for travellers in Spain and readers at home. London: John Murray, Albermarle Street.

GautierThèophile (1845). Voyage en Espagne. Paris: Charpentier, Libraire-Éditeur.

Giner de los Ríos Francisco ( I 885). Paisaje. La llustración artística de Barcelona. Reed. Revista Peñalara, Madrid, I9I5.

Kubler George (1983). La obra del Escorial. Madrid: Alianza Editorial.

López Serrano Matilde (1944). Patrimonio Nacional, Biblioteca de Palacio. Catálogo de Dibujos. I. Trazas de Juan de Herrera y sus seguidores para el Monasterio de El Escorial. Madrid: Patrimonio Nacional.

López Torrijos Rosa (1985). Los años del Escorial: imágenes históricas y simbólicas. En El Escorial en la Biblioteca Nacional (Catálogo de la exposición). Madrid: Ministerio de Cultura, 1985, pp. 51-6I.

Ortega y Gasset José (1966). Meditación del Escorial. En El Espectador VI, Obras completas. Madrid, Editorial Revista de Occidente, 1966, vol. II, pp. 658-664.

Roberts David (1837). Sketches in Spain, taken during the years 1832- I 833. London: Hodcson \& Graves C. Hullmandel.

Rotondo Antonio ( I 863). Historia descriptiva, artística y pintoresca del Real Monasterio de San Lorenzo, vulgarmente llamado del Escorial. Madrid: D. Eusebio Aguado, Impresor de Cámara de S.M. y de su Real Casa.

San Jerónimo, fray Juan de (I59 I). Libro de memorias deste Monasterio de San Lorenzo El Real. Real Biblioteca del Monasterio de San Lorenzo de El Escorial, Ms. Cod. K-I-7.

Santiago Páez Elena, Magariños Juan Manuel (1985). El Escorial, historia de una imagen. En El Escorial en la Biblioteca Nacional (Catálogo exposición). Madrid: Ministerio de Cultura, 1985, pp. 223-348.

Sepúlveda Enrique, Comba Juan ( 1887$)$. La vida en Madrid en 1886. Madrid: Librería de Fernando Fe.

Taylor René (1967). Architecture and Magic: Considerations on the Idea of the Escorial. En Essays in the History of Architecture in honor of Rudolf Wittkower. London: Phaidon Press, 1967, pp. 81-109.

Tomás y Valiente Francisco (1994). Nacionalismos en broma y en serio. En Diario El País, I3 de noviembre, p. I3.

Unamuno Miguel de (1922). En el Escorial. En Andanzas y visiones españolas. Madrid: Renacimiento, pp. 48, 49.

\section{Autores}

Pilar Chías, Universidad de Alcalá, pilar.chias@uah.es

Tomás Abad, Universidad de Alcalá, tomas.abad@uah.es

Para citar este capítulo: Chías Pilar, Abad Tomás (2020). De Viajeros y dibujantes: el Monasterio de San Lorenzo de El Escorial, entre el mito y la leyenda/On travellers and draughtsmen: the Monastery of San Lorenzo de El Escorial, between myth and legend. In Arena A., Arena M., Brandolino R.G., Colistra D., Ginex G., Mediati D., Nucifora S., Raffa P. (a cura di). Connettere. Un disegno per annodare e tessere. Atti del $42^{\circ}$ Convegno Internazionale dei Docenti delle Discipline della Rappresentazione/Connecting. Drawing for weaving relationships. Proceedings of the 42th International Conference of Representation Disciplines Teachers. Milano: FrancoAngeli, pp. 3043-3062. 


\title{
On Travellers and Draughtsmen: the Monastery of San Lorenzo de El Escorial, between Myth and Legend
}

\author{
Pilar Chías \\ Tomás Abad
}

Abstract

Since its construction in the I 6th century the Monastery of El Escorial has left no one indifferent and aroused a large amount of myths and legends. In the 16th and 17th centuries these myths related to the personality of the founder King Philip II and to the role that played the Spanish Crown as the main safeguard of Catholicism, showing the building as the new Temple of Salomon, the Civitate Dei by St. Augustine, and the compendium of Counter-Reformation architectural and iconographic standards. After the over-prioritisation of ornament during the Baroque epoch, the Neoclassicists in the Academies of Art tried to present El Escorial as a model to imitate due to its formal sobriety. Half a century later travelers and illustrators influenced by Romanticism aimed to associate the Monastery to the image of a tyrant solitary King of an obscurantist country, that was as far from reality as profitable. After a period of increasing excursionists and vacationers, at the post-war period in the 20th century El Escorial was intentionally linked to the materialisation of the lost Spanish Empire. On the other hand, the monumental scale of the building, together with the many historic events that happened within its walls and its role as a royal pantheon, promoted legends and fantasies related to magic practices, black howling dogs and hidden treasures. Images that are the visual evidence of the history of an extraordinary built heritage.

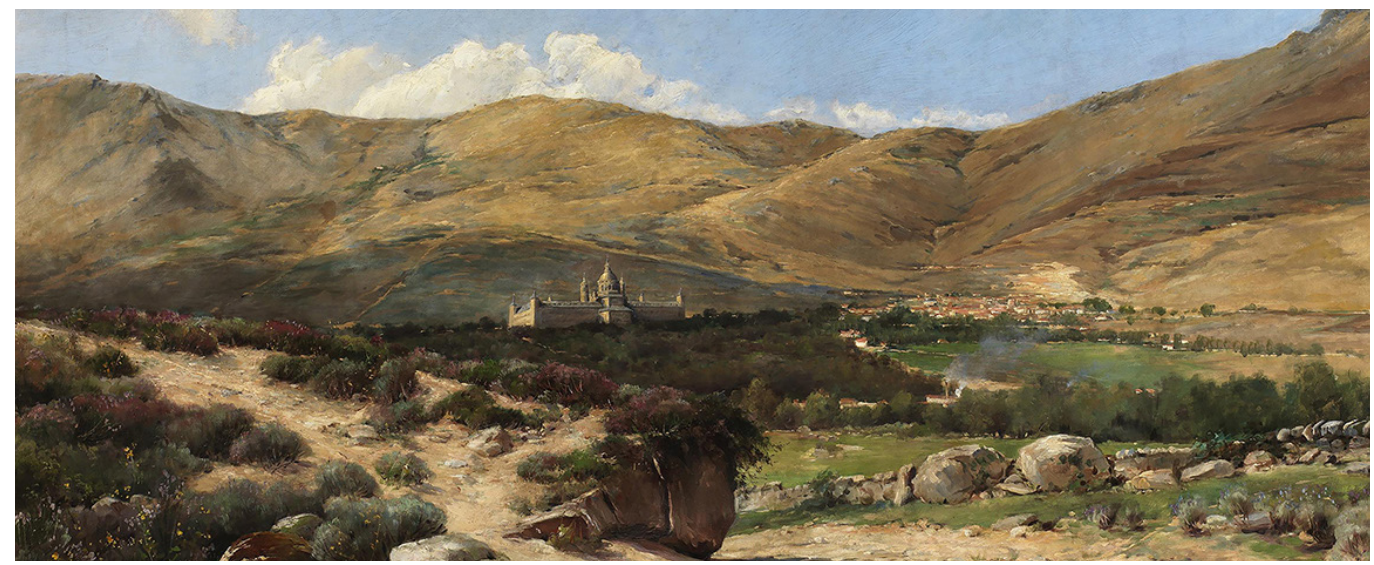




\section{Introduction. Main targets and methodology}

Since its creation in 1563 and due to its outstanding historical patrimonial value, the Monastery of El Escorial was the image carved in stone -'the slabbed stone' by Ortega y Gasset [Ortega y Gasset 1916-1934, vol. II, pp. 658-664]- of many ideas and interpretations. Its magnificent size outlines against the imposing mountain of Abantos, claiming for emotions and feelings that were frequently influenced both by contemporary aesthetics and current affairs.

Accordingly, the main target is to determine the myths built up of the Monastery along the centuries, and to analyse the way they affected its image and objective values.

From a methodological point of view, at a first stage we searched for documentation in a comprehensive manner in the main libraries, archives and museums, to get a broad overview of texts and images produced in each epoch. Then we classified the various documents in accordance with the most significant periods, as follows: I) the King's eulogists; 2) the Escorial as a new model to imitate; 3) the romantic travelers; 4) excursionist and vacationers; and 5) the Monastery as the image of a lost empire.

From this classification we chose some significant texts and images aiming to compare their level of alignment and complementarity, in order to foster the timely discussion about the various perspectives.

In parallel we revised the main living legends of the building as reflections of a period. Conclusions deal with the parallelism of both types of documents and their relationships with trends and historic facts.

In addition to the works by the authors [Chías 2013; Chías 2016; Chías, Abad 20I5; Chías, Abad 2018] there are almost no precedent researches focusing in this subject, but the book chapters by López Torrijos [López Torrijos 1985] and by Santiago Páez and Magariños [Santiago Páez y Magariños 1985] must be stressed, as well as the interesting symposium Literatura e Imagen en El Escorial edited by Campos y Fernández de Sevilla [Campos y Fernández de Sevilla 1996].

Fig. I. Luis Cabrera de Córdoba, 1619: de Felipe Segundo, Rey de España.

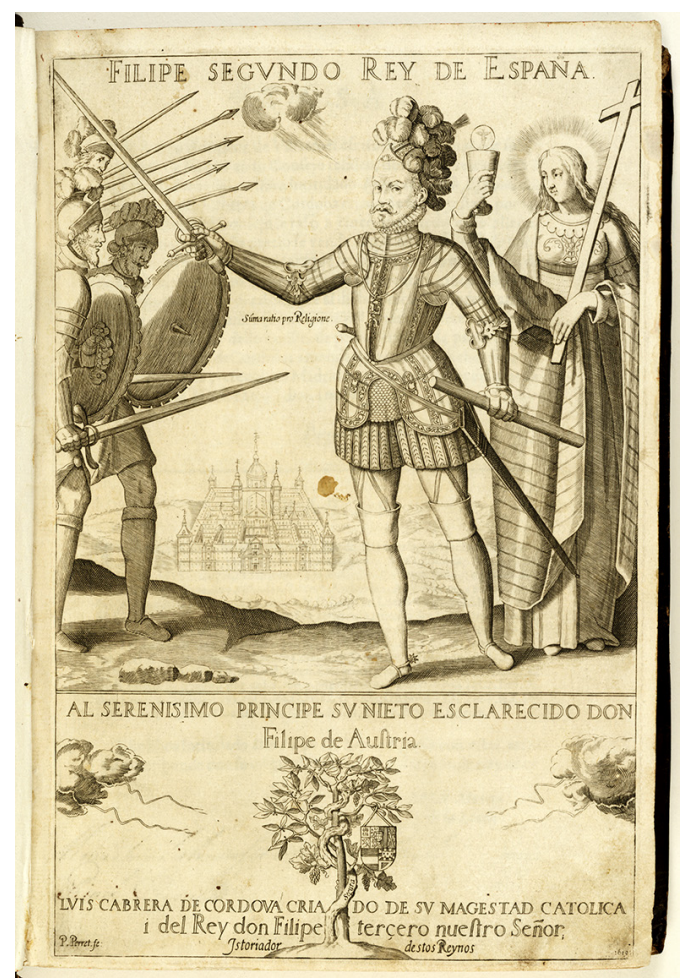




\section{Images by the 16th century eulogists: the Temple of Solomon, the Civitate Dei and the Counter-Reformation}

Along the 16th and 17th centuries prevailed the official image produced by the King Philip II eulogists, even when the Baroque aesthetic became increasingly important in opposition to the ornamental sobriety of the Monastery. "Such a big machine was richly built, saint, crafty, with great profit; the eight wonder in the world regarding order, and the first in dignity, [...] As a shame for the heretic enemies of the Catholic Church who destroyed overall temples with impiety and tyranny. And as a way to show them that he [King Philip II] will never get tired of favouring the Christian faith even using weapons. Such Temple was continuously extended and built, as big as his faith was, ennobling Spain" [Cabrera 1619, BookVI, p. 3I5]. During this period, the King's virtues deserved him to be considered as the new Solomon, wise and clever, and a staunch defender of the ideas of the Counter-Reformation (fig. I). As a consequence the Monastery was compared to the Temple of Jerusalem, whilst its iconography was constrained according to the severe guidelines imposed by the Council of Trent. On the other hand, the Hieronymite Order followed the Rule of St. Augustine, and the relationship between the Monastery and the Civitate Dei became a recurrent image of the Monastery, as shown in the simplified model of the building that lies on top of the book of St. Augustine in Sánchez Coello's painting [Estal 1964, p. 578], (fig. 2).

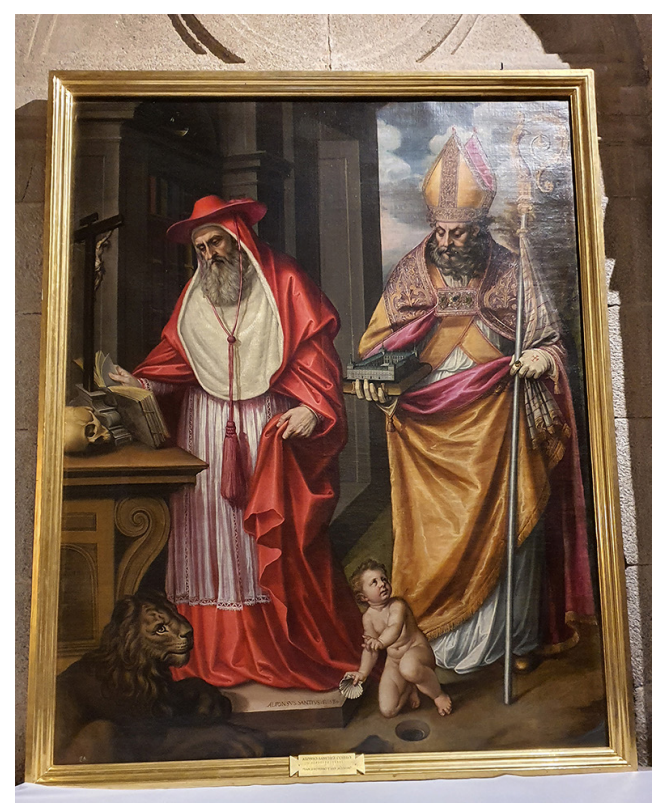

\section{El Escorial and the Academy}

Coinciding with the aesthetic change fostered by the Academies of Arts, El Escorial returned to being an object of interest. As a reference to the new classical architecture, it resumed the tradition of Juan de Arfe and Diego de Siloé, who regarded the building as the comprehension of the "restored architecture, the old one of Greeks and Romans" [Arfe I 585- | 587, Title I, Book IV].

To this end, Count of Aranda ordered an accurate surveying of the Monastery to be developed between 1757 and 1759 by José de Hermosilla and the military engineers Fillera and Bécaud. Drawings should have been used to produce a series of engravings to diffuse the image of the monument. 
Such an outstanding collection of large-scale manuscript plans were recently published by [Chías 20 17], together with a set of contemporary drawings that aimed to place value on such an interesting building (fig. 3).

In accordance with this insight, King Charles III sent in 1765 to the Academy a collection of ten Estampas (engravings) by Herrera and Perret to be studied by the students of Architecture' [López Serrano 1944, p. 5].

After his death, minister Campomanes summarised the zeitgeist as follows: "How sublime, what an unexplainable beauty in its majestic simplicity, where art is admired and artifice is ignored!' [Descripción 1789].

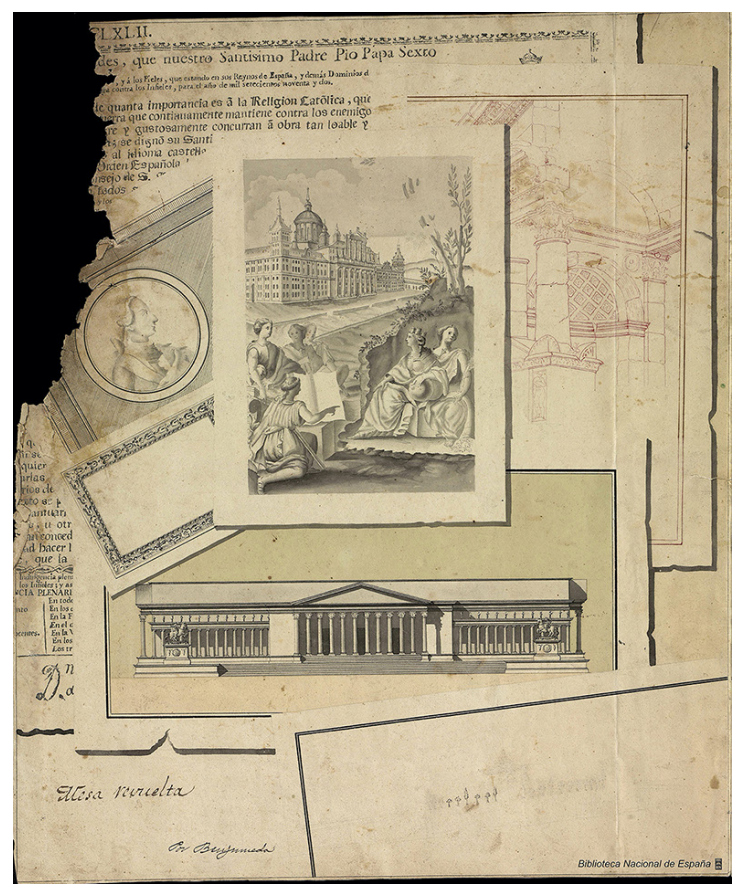

\section{The Romantic travellers}

After the short Neoclassical period, the new aesthetic of Romanticism was spread by writers and travelers, but also by artists who described Spain as an old-fashioned backward country, where legends of moors, bandits and bullfighters had an appearing leading role. Thèophile Gautier outlined the situation: "Une constitution sur l'Espagne, c'est une poignée de plâtre sur du granit" [Gautier 1859, p. 20].

During their trip, many authors produced outstanding sketches representing unprecedented perspectives of the Monastery and its environment. In many cases they were reworked later to be engraved and printed. Among the main draughtsmen were Chapuy [Chapuy 1842] (fig. 4), Ford [Ford I845], Guesdon [Guesdon I855] and Doré [Davillier, Doré I874] (fig. 5). Other authors decided to recruit excellent illustrators. This is the case of Manuel Cuendias [Cuendias I848] illustrated by Pannemaker, and of Émile Begin [Begin 1852] with drawings by the Frères Rouargue.

Such perspective views of the set of El Escorial were drawn shortly after the Peninsular War and show the damages and effects of pillage carried out by the French, as well as the consequences of the exclaustration of the Hieronymite Order. Though they are quite subjective and picturesque, and use chiaroscuro among other light effects, they are particularly interesting to analyse the situation of the building in the first half of the 19th century, depicting some details as the canvas covers on the southern façade, the white wooden carpentry, some enclosures at the Wall of the Niches, and even the activities developed by the inhabitants of San Lorenzo. 
Fig. 4. Nicolas-MarieJoseph Chapuy, 1842: de l'Escurial In L'Espols

ves Ies princip Espagne, vues des principales villes Lam. 381.

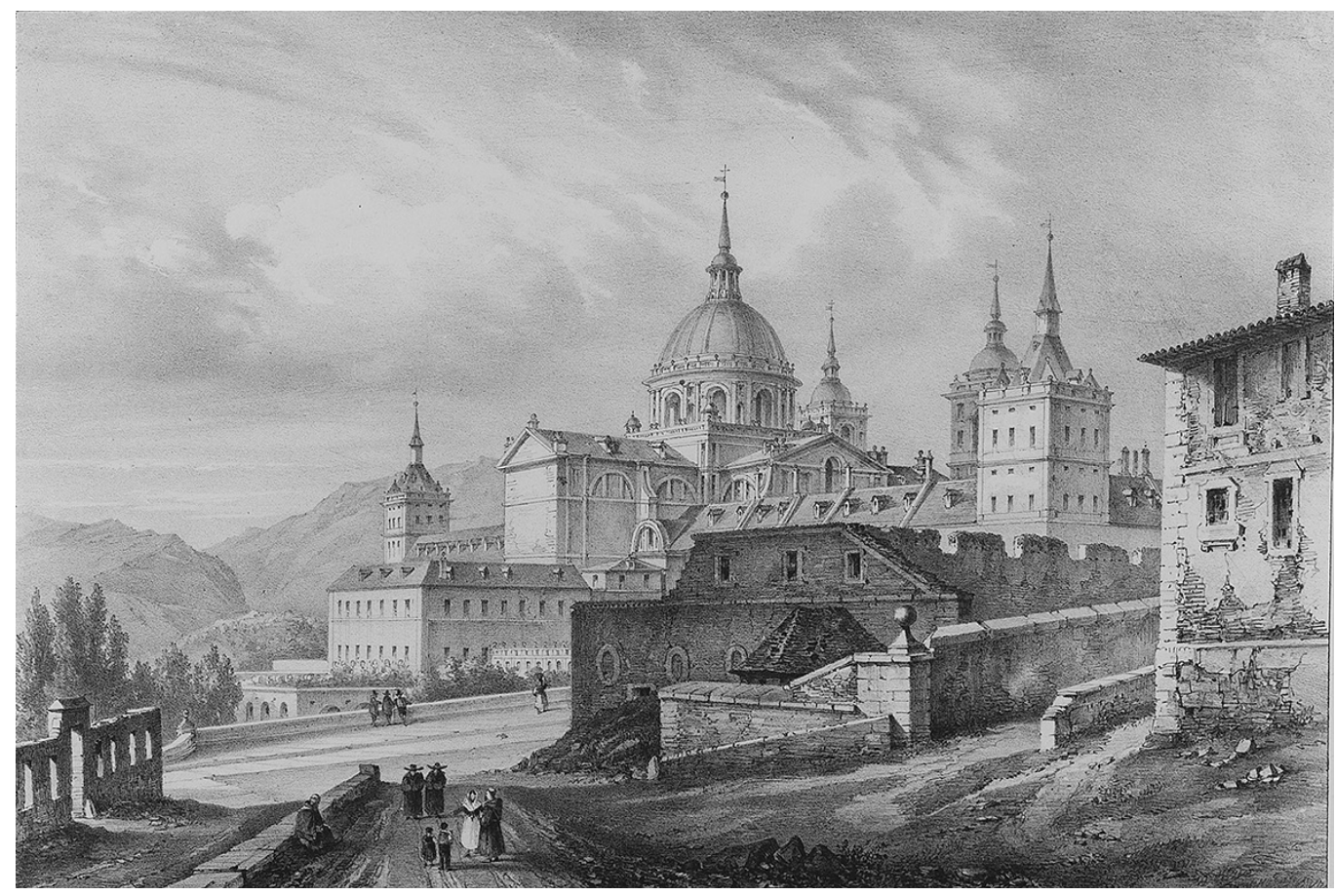

Fig. 5. Gustave Doré, I 860: L'Escurial: vue générale. In Davilliery Doré 1874, L'Espagne, p. 617 .

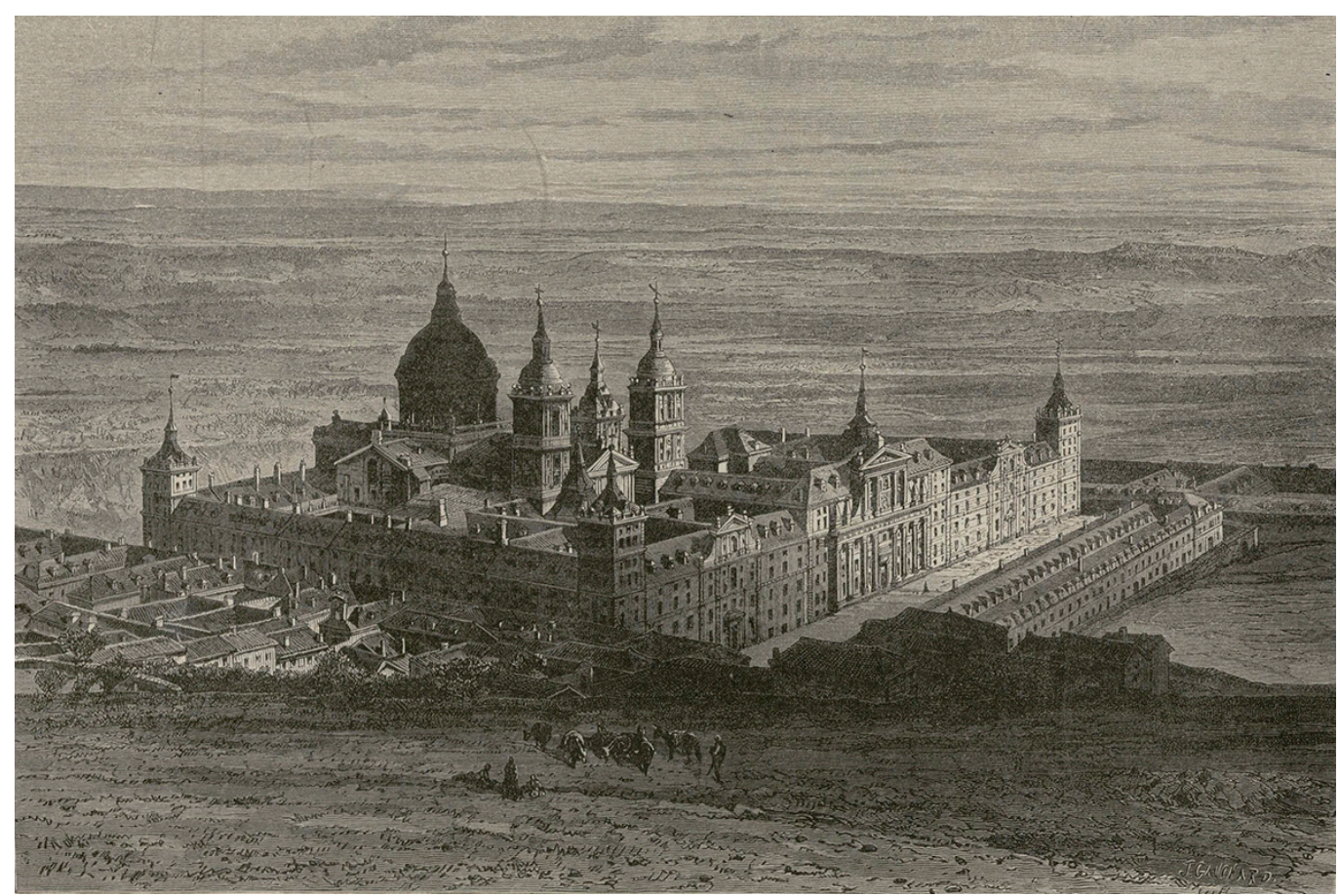




\section{Excursionists and Guides for travellers}

Between 1850 and the end of the Civil War the image of the Monastery was gradually associated with a holiday destination near Madrid, and was reinforced with the arrival of the railway.

In this period many guides and descriptions of the summer activities performed in San Lorenzo were abundant. Pieces of news appeared frequently in illustrated magazines (fig. 6), and novels set in the mountains showed an unknown rich environment linked to excursions (fig. 7) and to a new vision of the countryside as a source of health and knowledge that was fostered by the Institución Libre de Enseñanza.

Francisco Giner de los Ríos was a developer of a new wide concept of landscape and a comprehensive look to aspects that were not considered before, as the inhabited nature and the sterile desolate moorland. 'In its widest sense, landscape is the perspective of a natural area as landscape painting is the representation of such perspective' [Giner 1915], (fig. 8).

Fig. 6. Alcázar, 1885: El Escorial. Arrival of the funeral procession [of King Alphonse XII] to the Lonja of the Royal Monastery of San Lorenzo. La llustración Española y Americana, December 8th, 1885.

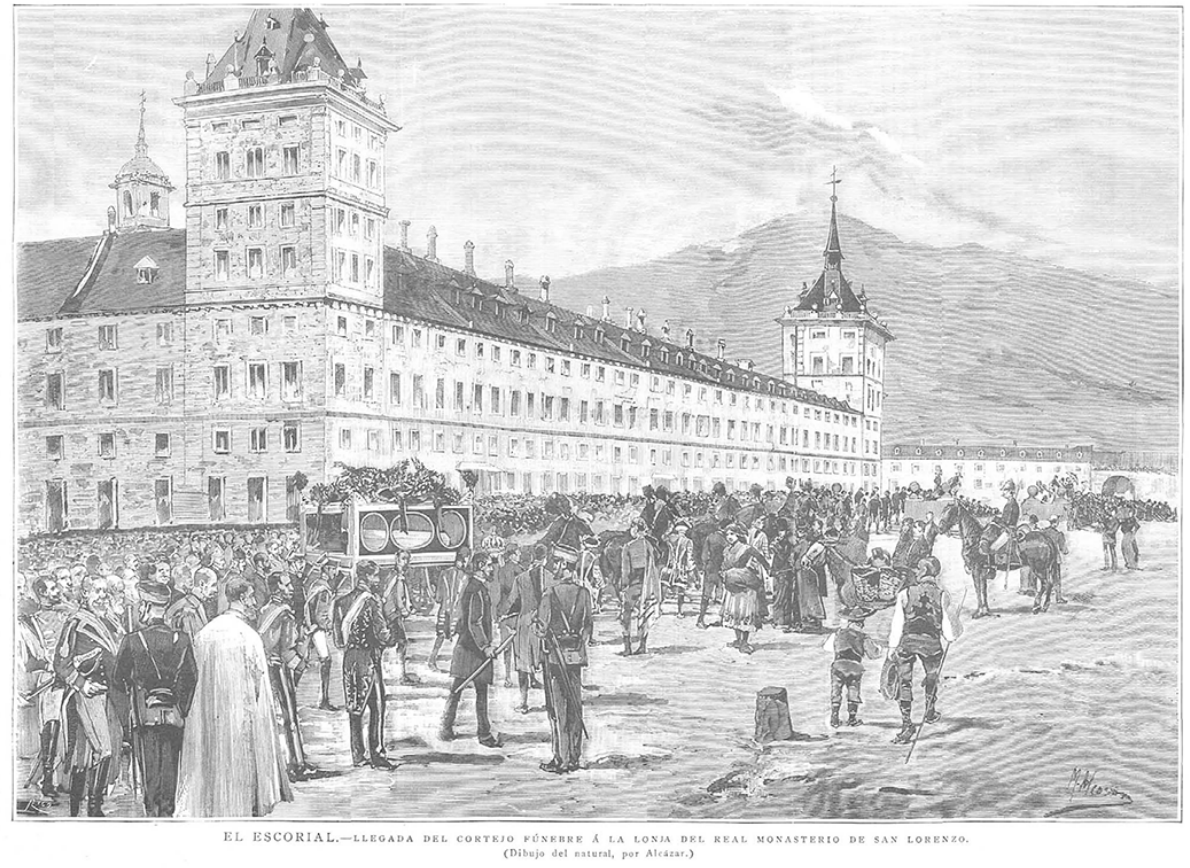

Biblioteca Nacional de Espaía

\section{Image and nostalgia of a lost Empire}

Since the establishment of the Second Republic in 193I and during Franco's dictatorship the Monastery became a symbol of Hispanidad (Hispanicism) and of the wide Empire of the Spanish Crown between the 16th and the 19th centuries. It was a part of a comprehensive strategy to regain the trust of population in the strong potential of the Country by using art and culture.

'The first area of nationalist mythologization is always History', wrote wisely Tomás y Valiente [Tomás y Valiente 1994, p. 13], and accordingly propaganda associated the building with unknown connotations and values supposedly inherent to the Spanish character.

Partly as a result of the aesthetic of posters (fig. 9), book covers (fig. I0), stamps and notes, as well as in other graphic media, some prejudices were adopted that were totally foreign to the building itself.They still survive and sometimes hinder from experiencing an objective approach to the building. 
Fig. 7. Juan Comba I 882: Leisure travels to Escoria In Sepúlveda y Comba 883, La vida en Madrid en I 882. Madrid: Librería de Fernando Fe.

Fig. 8. Félix Borrell 1901, Paisaje de El Escorial.

Museo Nacional de

Prado, Madrid.

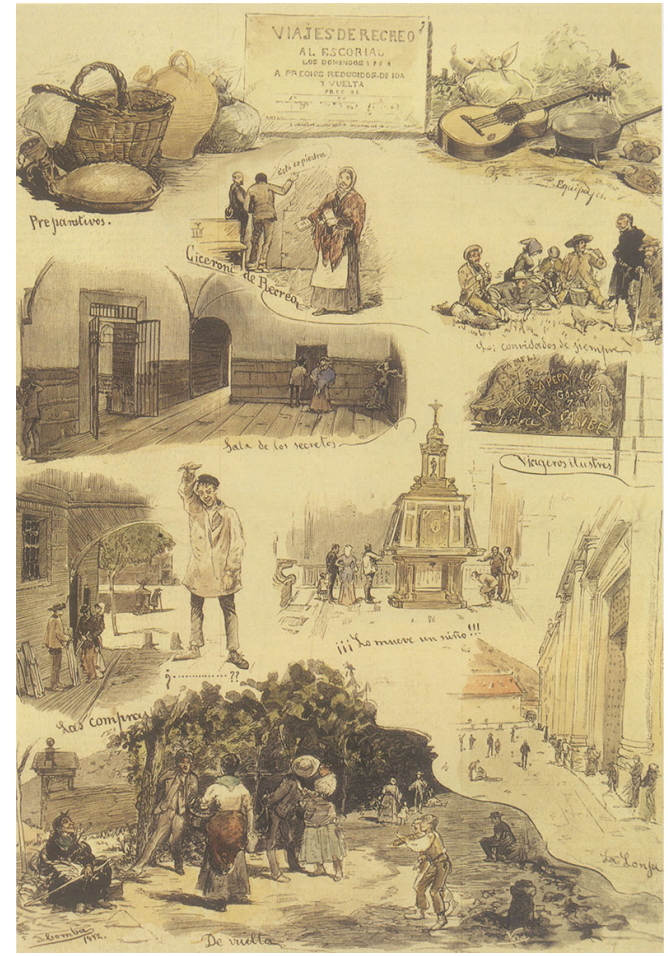

The representation of the Monastery at the background of two portraits by painter Salvador Dalí -of ambassador Juan de Cárdenas painted about 1943, and of Franco's oldest granddaughter dated 1974- are particularly interesting. The significant presence of the building becomes a unique symbolic background.

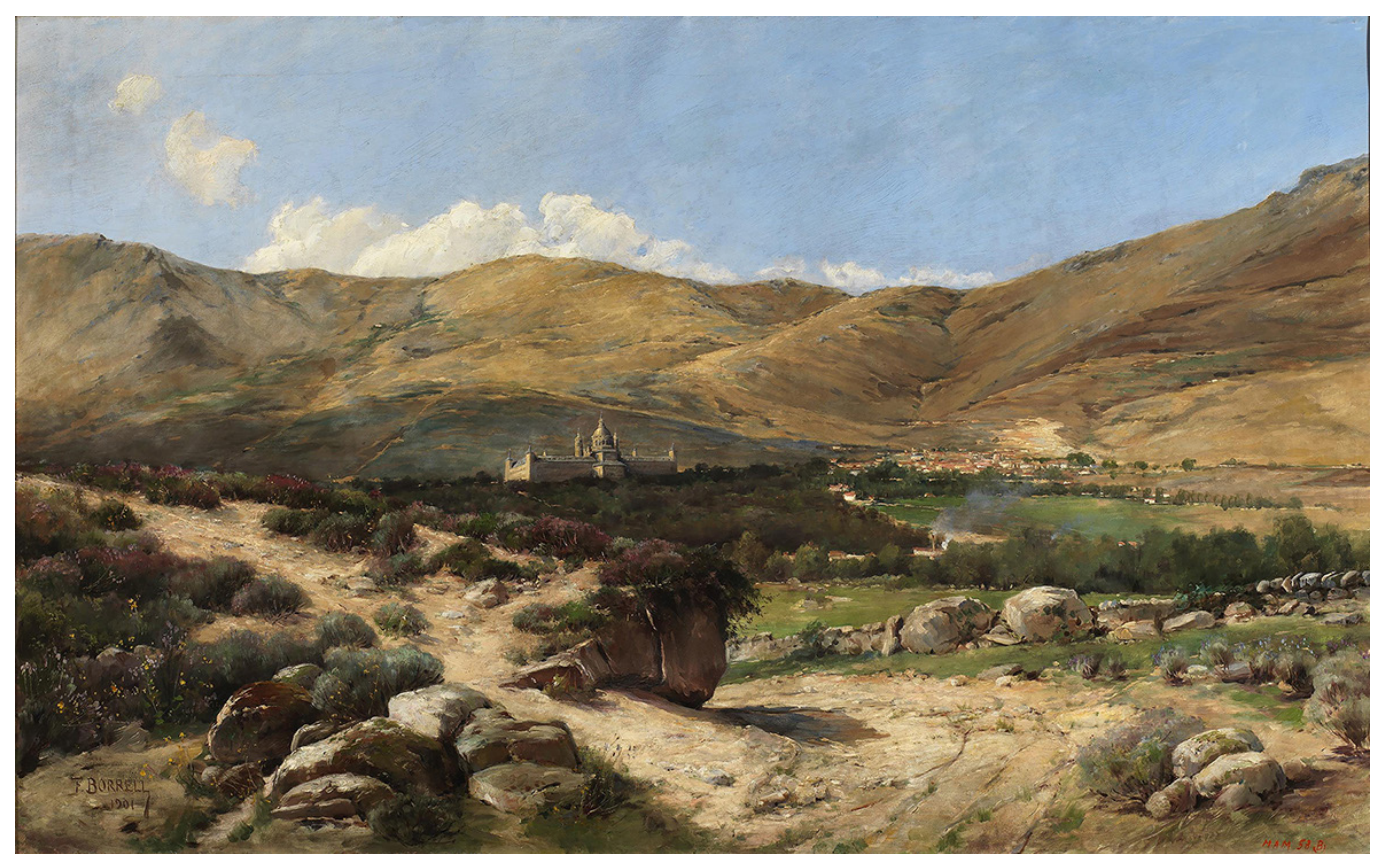


Fig. 9. Poster of a Congress of Juventud de Acción Popular, 1934. Biblioteca Nacional de España.

Fig. 10. Carrillo, 1944: Book cover of the scholar manual España es así. Madrid: Editorial Escuela Española.
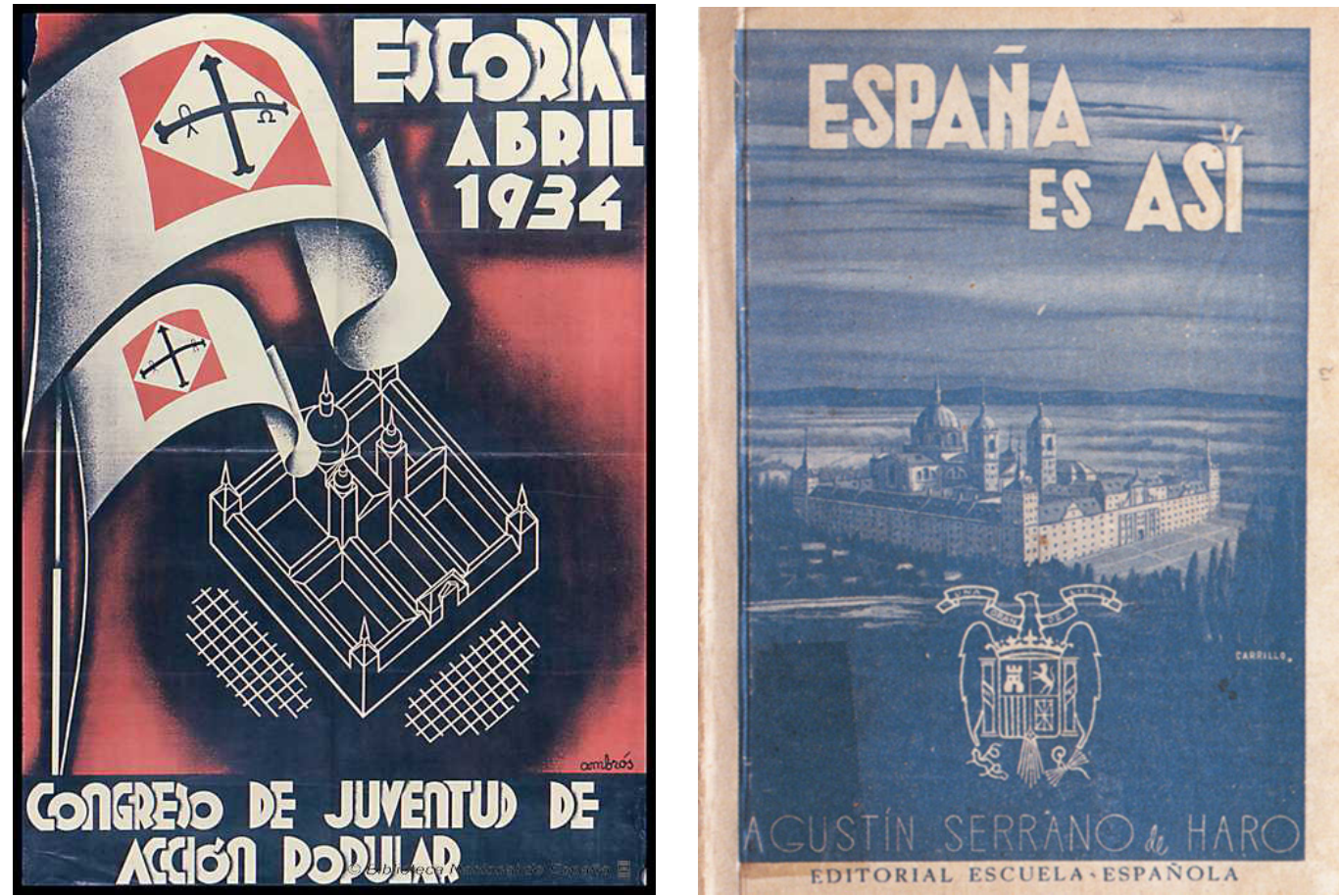

\section{Legends}

Legends associated to the building appeared at critical times as the construction of the building in he 16 th century or the invasion of Napoleon troops at the beginning of the 19th century.

Among the ideas that inspired King Philip II to build the Monastery, a heterodox interest in astrology and occult knowledge has been reported [Taylor 1967; Kubler 1983, pp. 170- 173]. Frescoes at the Royal Library (fig. I I) show some iconographies related to these interests, when they just evidence the contemporary knowledge and erudition.

However, the search for regulating outlines and magic proportions was relentless, and ensuing conclusions produced strange forced results.

The legend of the black dog goes back to the construction in August 1577, when the unfortunate animal roamed the works howling painfully in search of his master. At night he used to shelter in the 'chapel of the stairs' in the garden, what echoed his moaning causing fright among workers who thought that the devil was crying. The 'bad legend against the house' [San Jerónimo 1591, ff. 98-98v] did not have a happy ending, but some nights it can still be heard the sad howling merged with the blowing wind.

More recent is the legend of treasure that was hidden inside the Monastery to save it from the French rapine. According to Rotondo [Rotondo I863, pp. I83, I 84, I 86], the friars greeted in 1807 the spy of Napoleon Frèderick Quillet when he visited the Monastery to find out its riches. As the friars noticed his intention, they concealed a huge treasure that was never found. 
Fig. I 1. Pellegrin Tibaldi, |586- I591: Sketch for the frescoes in the Royal Library, with manuscrip Herrera British l London.

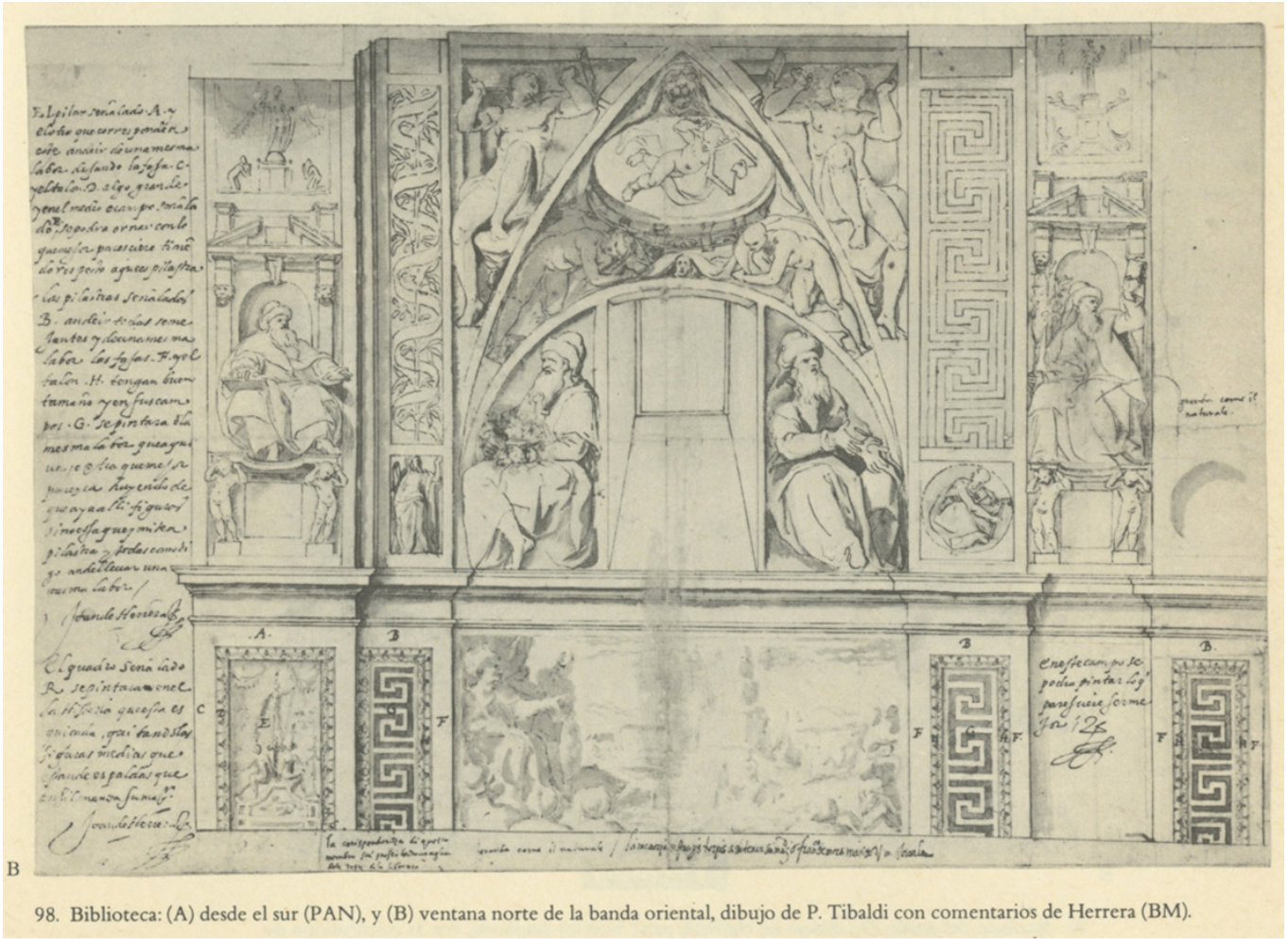

\section{Conclusions}

A comparative analysis of texts and images lead to two main consequences. On the one hand, both discourses are complementary and parallel, showing the same ideology and aesthetic thought through different means. On the other hand, turning points coincide with the essential milestones in the history of the Monastery.

Similarly, in the majority of cases legends were fed with the association of the building with supernatural phenomena.

Myths and legends highlight what Unamuno accurately summarized:" The fact is that almost none of the visitors to El Escorial arrive in a calm spirit to get the impression of an art work, to enjoy the sophisticated viewing of naked architecture. Almost everybody arrive with ideological blinkers, or political or religious prejudices, in one sense or another. In spite of being just pilgrims in search of art, they become progresists or conservatives, catholics or free thinkers. They look for the shadow of King Philip II, poorly known and misunderstood, and if they do not find it, they just imagine it" [Unamuno 1922, pp. 48, 49].

\section{References}

Arfe y Villafañe Juan de (I585- 1587). De Varia commensuración para la esculptura y architectura. Sevilla: Andrea Pescioni y Juan de León.

Begin Émile (1852). Voyage pittoresque en Espagne et en Portugal. Paris: Belin-Leprieur et Morizot.

Cabrera de Córdoba Luis (1619). Historia de Felipe Segundo, Rey de España. Madrid: Luis Sánchez, impresor del Rey.

Campos y Fernández de Sevilla Francisco Javier (dir). (1996). Literatura e imagen en El Escorial (Actas del simposium). San Lorenzo de El Escorial: Real Colegio Universitario $M^{a}$ Cristina.

Chapuy Nicolas-Marie-Joseph ( 1842$)$. L'Espagne. Vues des principales villes de ce Royaume dessinées. Paris: Lemercier, Berciard et Cie. 
Chías Pilar (2013). Territorio y paisaje en el entorno del Monasterio de San Lorenzo de El Escorial: planos y vistas desde el dibujo de Hatfield House a Guesdon. In Revista EGA n² 22, pp. 38-49.

Chías Pilar (20 I 6). La iconografía del Monasterio de El Escorial:Tradición e innovación en cuatro siglos de imágenes impresas. In Revista EGA, 28, 2016, pp. 32-43.

Chías Pilar (20 I7). Dos siglos de revitalización en la iconografía del Monasterio de el Escorial, I 600- I 800. In Revista EGA, 29, 22, 2017, pp. 28-37.

Chías Pilar, Abad Tomás (20I5). La Imagen de San Lorenzo de El Escorial desde las Ordenanzas de Carlos III. In M.A. Chaves (ed.). Arquitectura, Patrimonio y Ciudad. Madrid: Universidad Complutense de Madrid / CSIC, 20 I 5, pp. I 05 - I I 2.

Chias Pilar, Abad Tomás (20 8). From Woodcut engravings to Photography: Printed images of the Monastery of El Escorial in the 19th Century. In Disegnare Idee Immagini, 57, 20। 8, pp. 36-45.

Cuendias Manuel de, Féréal Victor de ( 1848$)$. L'Espagne pittoresque, artistique et monumentale: moeurs, usages et costumes. Paris: Librairie Ethnographique.

Davillier Baron Jean Charles, Doré Gustave ( 1874). L'Espagne. Paris: Librairie Hachette et Cie., 79 Boulevard Saint-Germain.

Descripción de los ornatos públicos con que la corte de Madrid ha solemnizado la feliz exaltación al trono de los reyes nuestros señores don Carlos IIII y doña Luisa de Borbón, y la jura del serenísimo señor don Fernando, príncipe de Asturias. In la Imprenta Real de Madrid, I789.

Estal Gabriel del (1964). El Escorial en la transición de San Jerónimo a San Agustín (Titularidad jurídica y circunstancia histórica). In Monasterio de San Lorenzo el Real, El Escorial, 1964, pp. 578-584.

Ford Richard ( 1845). A handbook for travellers in Spain and readers at home. London: John Murray, Albermarle Street.

GautierThèophile (1845). Voyage en Espagne. Paris: Charpentier, Libraire-Éditeur.

Giner de los Ríos Francisco ( I 885). Paisaje. La llustración artística de Barcelona. Reed. Revista Peñalara, Madrid, I9I5.

Kubler George (1983). La obra del Escorial. Madrid: Alianza Editorial.

López Serrano Matilde (1944). Patrimonio Nacional, Biblioteca de Palacio. Catálogo de Dibujos. I. Trazas de Juan de Herrera y sus seguidores para el Monasterio de El Escorial. Madrid: Patrimonio Nacional.

López Torrijos Rosa (1985). Los años del Escorial: imágenes históricas y simbólicas. In El Escorial en la Biblioteca Nacional (Catálogo de la exposición). Madrid: Ministerio de Cultura, 1985, pp. 51-6I.

Ortega y Gasset José (1966). Meditación del Escorial. In El Espectador VI, Obras completas. Madrid, Editorial Revista de Occidente, 1966, vol. II, pp. 658-664.

Roberts David (1837). Sketches in Spain, taken during the years 1832- I 833. London: Hodcson \& Graves C. Hullmandel.

Rotondo Antonio ( I 863). Historia descriptiva, artística y pintoresca del Real Monasterio de San Lorenzo, vulgarmente llamado del Escorial. Madrid: D. Eusebio Aguado, Impresor de Cámara de S.M. y de su Real Casa.

San Jerónimo, fray Juan de (I59 I). Libro de memorias deste Monasterio de San Lorenzo El Real. Real Biblioteca del Monasterio de San Lorenzo de El Escorial, Ms. Cod. K-I-7.

Santiago Páez Elena, Magariños Juan Manuel (1985). El Escorial, historia de una imagen. In El Escorial en la Biblioteca Nacional (Catálogo exposición). Madrid: Ministerio de Cultura, 1985, pp. 223-348.

Sepúlveda Enrique, Comba Juan (I887). La vida en Madrid en I886. Madrid: Librería de Fernando Fe.

Taylor René (1967). Architecture and Magic: Considerations on the Idea of the Escorial. In Essays in the History of Architecture in honor of Rudolf Wittkower. London: Phaidon Press, 1967, pp. 8I- 109.

Tomás y Valiente Francisco (1994). Nacionalismos en broma y en serio. In Diario El País, I 3 de noviembre, p. I3.

Unamuno Miguel de (1922). En el Escorial. En Andanzas y visiones españolas. Madrid: Renacimiento, pp. 48, 49.

\section{Authors}

Pilar Chías, Universidad de Alcalá, pilar.chias@uah.es

Tomás Abad, Universidad de Alcalá, tomas.abad@uah.es

To cite this chapter. Chías Pilar, Abad Tomás (2020). De Viajeros y dibujantes: el Monasterio de San Lorenzo de El Escorial, entre el mito y la leyenda/On travellers and draughtsmen: the Monastery of San Lorenzo de El Escorial, between myth and legend. In Arena A., Arena M., Brandolino R.G., Colistra D., Ginex G., Mediati D., Nucifora S., Raffa P. (a cura di). Connettere. Un disegno per annodare e tessere. Atti del $42^{\circ}$ Convegno Internazionale dei Docenti delle Discipline della Rappresentazione/Connecting. Drawing for weaving relationships. Proceedings of the 42 th International Conference of Representation Disciplines Teachers. Milano: FrancoAngeli, pp. 3043-3062. 